\title{
MINERALIZATION OF NITROGEN AND CARBON FROM ORGANIC COMPOST FROM ANIMAL PRODUCTION WASTE ${ }^{1}$
}

\author{
MARIA DIANA MELO ARAÚJO ${ }^{2 *}$, MARINA MONTEIRO FEITOSA ${ }^{3}$, ANACLAUDIA ALVES PRIMO $^{4}$, CARLOS $^{2}$ \\ ALBERTO KENJI TANIGUCHI ${ }^{5}$, HENRIQUE ANTUNES DE SOUZA ${ }^{6}$
}

\begin{abstract}
Elucidating the mineralization of organic composts makes it possible to understand the release of nutrients to plants. The objective of this study was to evaluate the mineralization of nitrogen $(\mathrm{N})$ and carbon (C) from organic compost from residues of the production and slaughter of small ruminants, applied on a Neossolo Flúvico (Fluvents). The compost consists of remains of grass (forage), manure and slaughter residues such as blood, viscera and the carcass of goats and sheep. Under laboratory conditions, two experiments were conducted in a completely randomized design, considering the doses of organic compost at the following levels: zero; $3.75,7.5,15$ and $30 \mathrm{Mg} \mathrm{ha}^{-1}$. For the $\mathrm{N}$ and $\mathrm{C}$ mineralization tests, 11 and 32 collection times (sampling periods) were evaluated, respectively. Inorganic $\mathrm{N}$ content (ammonium and nitrate) was measured in the $\mathrm{N}$ mineralization test, and $\mathrm{CO}_{2}-\mathrm{C}$ concentration was quantified in the $\mathrm{C}$ mineralization test. The largest increments between the applied doses of organic compost from residues of the production and slaughter of small ruminants were $70 \%$ and $69 \%$ for potentially mineralizable $\mathrm{N}$ and $\mathrm{C}$, with amounts of 7.5 and $30 \mathrm{Mg} \mathrm{ha}^{-1}$ at doses of 3.75 and $7.5 \mathrm{Mg} \mathrm{ha}^{-1}$, respectively. Organic $\mathrm{C}$ and $\mathrm{N}$ from residues of the production and slaughter of small ruminants are rapidly mineralized in the soil (up to 45 days) due to their low $\mathrm{C} / \mathrm{N}$ ratio.
\end{abstract}

Keywords: Composting. Small ruminants. C/N ratio.

\section{MINERALIZAÇÃO DO NITROGÊNIO E CARBONO DO COMPOSTO ORGÂNICO PROVENIENTE DE RESÍDUOS DA PRODUÇÃO ANIMAL}

\begin{abstract}
RESUMO - A elucidação do processo de mineralização de compostos orgânicos permite entender a liberação de nutrientes para as plantas. Objetivou-se com este trabalho avaliar a mineralização de nitrogênio e carbono de composto orgânico proveniente de resíduos da produção e abate de pequenos ruminantes, aplicados sobre um Neossolo Flúvico. O composto consiste de restos de capim (forrageiras), estercos e resíduos do abate como sangue, vísceras e a carcaça de caprinos e ovinos. Em condições de laboratório, dois experimentos foram conduzidos em um delineamento inteiramente casualizado, considerando-se as doses de composto orgânico nos seguintes níveis: zero; 3,$75 ; 7,5 ; 15$ e $30 \mathrm{Mg} \mathrm{ha}^{-1}$. Para o ensaio de mineralização de nitrogênio e carbono foram avaliados 11 e 32 tempos de coletas (épocas de amostragem), respectivamente. No ensaio de mineralização de nitrogênio foi medido o teor de nitrogênio inorgânico (amônio e nitrato) e no experimento de carbono foi quantificado a concentração de $\mathrm{C}-\mathrm{CO}_{2}$. O maior incremento entre as doses aplicadas de composto orgânico proveniente de resíduos da produção e abate de pequenos ruminantes foi de $70 \%$ e $69 \%$ para o nitrogênio e o carbono potencialmente mineralizável com as quantidades de 7,5 e $30 \mathrm{Mg} \mathrm{ha}^{-1}$, em relação as doses de 3,75 e 7,5 $\mathrm{Mg} \mathrm{ha}^{-1}$, respectivamente. $\mathrm{O}$ carbono e o nitrogênio orgânico provenientes com composto de resíduos da produção e do abate de pequenos ruminantes são rapidamente mineralizados no solo (até 45 dias) devido à sua baixa relação $\mathrm{C} / \mathrm{N}$.
\end{abstract}

Palavras-chave: Compostagem. Pequenos ruminantes. Relação C/N.

\footnotetext{
*Corresponding author

${ }^{1}$ Received for publication in 04/02/2019; accepted in 04/03/2020.

${ }^{2}$ Center of Agrarian and Biological Sciences, Universidade Estadual Vale do Acaraú, Sobral, CE, Brazil; mariadianamello@gmail.com ORCID: 0000-0001-7050-1239.

${ }^{3}$ Department of Soil Science, Universidade Federal de Lavras, Lavras, MG, Brazil; marinamonteirof@gmail.com - ORCID: 0000-00022026-6338.

${ }^{4}$ Center of Science, Universidade Federal do Ceará, Fortaleza, CE, Brazil; anaclaudiaprimo@hotmail.com - ORCID: 0000-0002-96010224.

${ }^{5}$ Brazilian Agricultural Research Corporation, Embrapa Agroindústria Tropical, Fortaleza, CE, Brazil; carlos.taniguchi@embrapa.br ORCID: 0000-0002-1280-8678.

${ }^{6}$ Brazilian Agricultural Research Corporation, Embrapa Meio-Norte, Teresina, PI, Brazil; henrique.souza@embrapa.br - ORCID: 00000002-2209-4285.
} 


\section{INTRODUCTION}

The Brazilian Northeast region has the largest national herd of goats and sheep, approximately 7.7 and 9.0 million heads, respectively, and most of them belong to family farmers (MAGALHÃES et al., 2018). Considering that half of this herd consists of females, which generate one offspring per year, a natural mortality rate around $10 \%$, and an average carcass weight of $20 \mathrm{~kg}$, and that a composting process requires around $30 \mathrm{~kg}$ of structuring materials (remains of grass, manure, etc.) (OLIVEIRA et al., 2015), there would be a potential of 47,000 tons of organic compost every year.

The use of carcasses from the slaughter of ruminants for meat and bone meal production, as well as for the manufacture of feed for animal consumption, has been prohibited by the Ministry of Agriculture (BRASIL, 2004), thus limiting the alternatives for the disposal of the material. However, through the composting process, this byproduct of the goat and sheep production activity can be reintroduced into the production systems, avoiding possible environmental problems, recycling nutrients and enabling its use as organic fertilizer (SOUZA et al., 2019).

The semiarid region has low use of inputs, especially because of its low natural precipitation and dry spells, which lead to soil degradation, mainly due to the decrease in fertility (MENEZES et al., 2012). Therefore, the use of organic materials is extremely important, especially in low-tech systems (MENEZES et al., 2012; SOUZA et al., 2014a).

Therefore, the materials that can be generated in the property and have satisfactory nitrogen $(\mathrm{N})$ contents need to be evaluated for the potential and fraction of mineralization, which are information that provides basis for the use of organic materials in their application to the soil (ANDRADE; OLIVEIRA; CERRI, 2006; MANTOVANI et al., 2006). N stands out among the nutrients present in some residues, by-products and composts. This macronutrient usually limits crop development and increases the cost of production systems, especially for family farmers (MENEZES et al., 2012; SOUZA et al., 2014a). In addition to $\mathrm{N}$, and along with the degradation of carbon (C), it is possible to determine the agricultural use of wastes and composts based on their rate of mineralization in the soil (PAULA et al., 2013).

The data of organic materials to be obtained include the half-life period, release of the nutrient for a certain period of time and the fraction of mineralization, which can be used to calculate the rate of agronomic application that takes into account, mainly, the amount of $\mathrm{N}$ available (BOEIRA; MAXIMILIANO, 2004).

The objective of this study was to evaluate the mineralization of $\mathrm{N}$ and $\mathrm{C}$ from organic compost from residues of the production and slaughter of small ruminants, applied on a Neossolo Flúvico (Fluvents).

\section{MATERIAL AND METHODS}

Two experiments were carried out under laboratory conditions, one at Embrapa Goats and Sheep, Sobral, CE, to evaluate $\mathrm{N}$ mineralization according to Coscione and Andrade (2006) and the other at Embrapa Tropical Agroindustry, Fortaleza, $\mathrm{CE}$, to evaluate $\mathrm{C}$ degradation according to Anderson (1982), with some modifications. The soil used in both trials was the same, collected in Sobral, CE.

The compost used in both studies was produced in a compost bin, using the following materials: wastes (solid - remnants of slaughter such as blood, viscera) from slaughterhouses of goats and sheep, in addition to the carcass of animals, plus 1.5 to 2.0 times of the mixture of $50 \%$ manure from the cleaning of goat/sheep pens and $50 \%$ of feeder rejects (crushed elephant grass) and tree pruning residues, having $50 \%$ moisture, i.e. around $30 \mathrm{~kg}$ of structuring material. The period of production of the organic compost was 120 days, as reported by Souza et al. (2019).

The chemical characteristics of the compost (Table 1) were determined according to Abreu, Andrade, and Falcão (2006). After 120 days, the moisture content of the organic compost was $10 \%$.

Table 1. Average values of chemical attributes of the organic compost.

\begin{tabular}{|c|c|c|c|c|c|c|c|c|}
\hline $\mathrm{N}_{\mathrm{IN}}$ & $\mathrm{NO}_{3}{ }^{-}-\mathrm{N}$ & $\mathrm{NH}_{4}^{+}-\mathrm{N}$ & $\mathrm{N}_{\mathrm{T}}$ & $\mathrm{C}$ & $\mathrm{P}$ & $\mathrm{K}$ & $\mathrm{Ca}$ & $\mathrm{Mg}$ \\
\hline \multicolumn{9}{|c|}{---- $\mathrm{mg} \mathrm{kg}^{-1}$} \\
\hline 355 & 250 & 105 & 20.3 & 150.6 & 9 & 15.7 & 21.9 & 5.5 \\
\hline $\mathrm{Na}$ & $\mathrm{S}$ & $\mathrm{B}$ & $\mathrm{Cu}$ & $\mathrm{Fe}$ & $\mathrm{Mn}$ & $\mathrm{Zn}$ & $\mathrm{pH}$ & $\mathrm{C} / \mathrm{N}$ \\
\hline \multicolumn{9}{|c|}{---- $\mathrm{g} \mathrm{kg}^{-1}$---- } \\
\hline 2.1 & 2.8 & 20 & 30 & 2,051 & 175 & 138 & 6.7 & 7.4 \\
\hline
\end{tabular}

$\mathrm{N}_{\mathrm{IN}}$ - inorganic nitrogen; $\mathrm{NO}_{3}{ }^{-} \mathrm{N}$ - nitrate; $\mathrm{NH}_{4}{ }^{+}-\mathrm{N}$ - ammonium; $\mathrm{N}_{\mathrm{T}}$ - total nitrogen; $\mathrm{C}$ - carbon; $\mathrm{P}$ phosphorus; $\mathrm{K}$ - potassium; $\mathrm{Ca}$ - calcium; $\mathrm{Mg}$ - magnesium; $\mathrm{S}$ - sulfur; $\mathrm{Na}$ - sodium; $\mathrm{pH}$ - hydrogenionic potential $\left(\mathrm{CaCl}_{2}\right)$; B - boron; $\mathrm{Cu}$ - copper; $\mathrm{Fe}$ - iron; $\mathrm{Mn}$ - manganese; $\mathrm{Zn}$ - zinc. 
The soil used in the test was classified as NEOSSOLO FLÚVICO Tb Eutrófico (Fluvents), whose chemical characteristics were: $5.9,11,2,2$, 99, 10, 1, 112, 81, 1, 193, 58 and 1 respectively for $\mathrm{pH}_{(\mathrm{H} 2 \mathrm{O})}, \mathrm{OC}\left(\mathrm{g} \mathrm{kg}^{-1}\right), \mathrm{P}\left(\mathrm{mg} \mathrm{dm}^{-3}\right), \mathrm{K}, \mathrm{Ca}, \mathrm{Mg}, \mathrm{Na}$, $\mathrm{SB}, \mathrm{H}+\mathrm{Al}, \mathrm{Al}^{3+}, \mathrm{CEC}\left(\mathrm{mmol}_{\mathrm{c}} \mathrm{dm}^{-3}\right) ; \mathrm{V}$ and $\mathrm{m}(\%)$. Soil texture showed 185,195 and $620 \mathrm{~g} \mathrm{~kg}^{-1}$ of clay, silt and sand, respectively.

The doses of compost added to the soil used in the experiment were: zero, 3.75, 7.5, 15 and 30 $\mathrm{Mg} \mathrm{ha}^{-1}$, without leaching, i.e., the amount of water applied was controlled by gravimetry, because there was no drainage. The dose of $7.5 \mathrm{Mg} \mathrm{ha}{ }^{-1}$ corresponds to the $\mathrm{N}$ recommendation for corn yield of $8 \mathrm{Mg} \mathrm{ha}^{-1}$ (considering the recommended amounts for application at planting - $30 \mathrm{~kg} \mathrm{ha}^{-1}$ and for topdressing fertilization - $80 \mathrm{~kg} \mathrm{ha}{ }^{-1}=110 \mathrm{~kg} \mathrm{ha}^{-1}$ ) (ALVES et al., 1999). The $\mathrm{N}$ content present in the compost $\left(20 \mathrm{~g} \mathrm{~kg}^{-1}\right)$ and the moisture content of the compost $(10 \%)$ were considered in the calculations.

The procedure adopted by Coscione and Andrade (2006) was used to obtain the $\mathrm{pH}$ neutralization curves. For this, $100-\mathrm{mL}$ portions of soil were mixed with the doses of organic compost and the necessary amounts of $\mathrm{CaCO}_{3}$ for the soil to reach $\mathrm{pH}=6.5$.

\section{N mineralization test (COSCIONE; ANDRADE, 2006)}

The experimental design was completely randomized, in a split-plot scheme, with the plots being constituted by the compost doses and the subplots by the collection times (sampling periods for analysis), with three replicates.

Soil samples of $100 \mathrm{~g}$ with the five doses of compost were placed in $0.25-\mathrm{dm}^{3}$ polyethylene vials and kept under controlled conditions (temperature around $29 \pm 2.5^{\circ} \mathrm{C}$ ).

The incubation period consisted of 11 collections at different times, with analysis of the samples at the following times: $0,7,14,28,42,56$, $70,84,98,112$ and 126 days. The moisture content was monitored daily by weighing the vials and corrected to $60 \%$ of soil water retention capacity, according to Coscione and Andrade (2006).

On the predetermined dates, the plots corresponding to each treatment were disassembled and analyzed for inorganic $\mathrm{N}$, according to the method proposed by Cantarella and Trivelin (2001), which consists of the distillation of soil extracts in 1 mol L ${ }^{-1} \mathrm{KCl}$, in micro-Kjeldahl distillation apparatus, with subsequent titration of the distillate. Soil moisture was measured and the results were determined based on dry soil.

Concomitantly to inorganic $\mathrm{N}$ evaluation, $\mathrm{pH}$ was determined at $0,28,70,98$ and 126 days of incubation. Also, electrical conductivity was evaluated at 28, 70, 98 and 126 days. Both analyses were performed according to the methodology of Coscione and Andrade (2006).

\section{C degradation test (ANDERSON, 1982)}

This trial was also conducted using a completely randomized experimental design, in a split-plot scheme, with the same doses used in the $\mathrm{N}$ mineralization test, with four replicates. The incubation times were: $1,2,3,4,5,6,7,9,13,17$, $20,24,27,31,34,38,41,48,56,63,76,83,91,98$, $105,111,118,126,132,146,160$ and 180 days.

Soil samples with organic compost and $\mathrm{CaCO}_{3}$ were homogenized and placed in a $150-\mathrm{mL}$ plastic cup, and then deionized water was added to increase soil moisture to $70 \%$ of the water retention capacity. The plastic cups were placed in $0.9-\mathrm{L}$ glass pots with airtight closure. Two $50-\mathrm{mL}$ plastic cups were placed in each pot: one with $40 \mathrm{~mL}$ of water, to keep moisture in the environment, and the other with $20 \mathrm{~mL}$ of $0.5 \mathrm{~mol} \mathrm{~L}^{-1} \mathrm{NaOH}$ solution, to adsorb the $\mathrm{CO}_{2}-\mathrm{C}$ released by the mixture of soil and organic compost. Every time a cup containing the $\mathrm{NaOH}$ solution was replaced $0.5 \mathrm{~mL}$ of $1.5 \mathrm{~mol} \mathrm{~L}^{-1} \mathrm{BaCl}_{2}$ solution was added and the sample was titrated with a standardized solution of $0.4 \mathrm{~mol} \mathrm{~L}^{-1} \mathrm{HCl}$. The accumulated amount of $\mathrm{CO}_{2}$ emitted was converted into $\mathrm{CO}_{2}-\mathrm{C}$, and the result was expressed in $\mathrm{mg} \mathrm{kg}^{-1}$ of dry soil. The amount of $\mathrm{CO}_{2}-\mathrm{C}$ in the control treatment was subtracted from the amount of $\mathrm{CO}_{2}-\mathrm{C}$ of the treatment corresponding to each dose of organic compost.

\section{Statistical analysis}

The results of inorganic $\mathrm{N}$ and $\mathrm{CO}_{2}-\mathrm{C}$ were subjected to analysis of variance and nonlinear regression, with fit of the first-order kinetics model proposed by Stanford and Smith (1972):

$$
C_{m} \text { or } N_{m}=C_{0} \text { or } N_{0}\left(1-\exp ^{-k t}\right), \text { where, }
$$

$\mathrm{C}_{\mathrm{m}}$ or $\mathrm{N}_{\mathrm{m}}=$ mineralized carbon or nitrogen at time $\mathrm{t}$, in $\mathrm{mg} \mathrm{kg}^{-1}$;

$\mathrm{C}_{0}$ or $\mathrm{N}_{0}=$ potentially mineralizable carbon or nitrogen from the organic compost, in $\mathrm{mg} \mathrm{kg}^{-1}$;

$\mathrm{k}=$ mineralization constant of the organic compost, per day, and

$\mathrm{t}=$ time, in days.

The half-life $\left(\mathrm{T}^{1} / 2\right)$, which corresponds to the time, in days, required for the mineralization of $50 \%$ of the potentially mineralizable $\mathrm{C}$ or $\mathrm{N}$, was obtained using the following equation:

$$
T_{1 / 2}=\frac{\ln 2}{k}, \text { where, }
$$

$\ln 2=$ Napierian logarithm of 2, and

$\mathrm{k}=$ mineralization constant (carbon or 
nitrogen) of the organic compost, per day.

The biodegradation rate $(\mathrm{BR})$ or mineralization rate (MR), expressed in \%, and corresponding to the amount of mineralized $\mathrm{C}$ or $\mathrm{N}$ in relation to the amount of $\mathrm{C}$ or $\mathrm{N}$ added in the form of organic compost, was calculated according to Coscione and Andrade (2006):

$$
B R \text { or } M R=\left[\frac{\left(C_{x} \text { or } N_{x}\right)-\left(C_{0} \text { or } N_{0}\right)}{C_{\text {added }} \text { or } N_{\text {added }}}\right] \times 100, \text { where, }
$$

$\mathrm{C}_{\mathrm{x}}$ or $\mathrm{N}_{\mathrm{x}}=$ mineralized carbon or nitrogen at the $x$ dose of organic compost, in $\mathrm{mg} \mathrm{kg}^{-1}$;

$\mathrm{C}_{0}$ or $\mathrm{N}_{0}=$ mineralized carbon or nitrogen at the zero dose of organic compost, in $\mathrm{mg} \mathrm{kg}^{-1}$; and

$\mathrm{C}_{\text {added }}$ or $\mathrm{N}_{\text {added }}=$ amount of carbon or nitrogen added in the form of organic compost, in $\mathrm{mg} \mathrm{kg}^{-1}$.

\section{RESULTS AND DISCUSSION}

For the values of $\mathrm{NH}_{4}^{+}-\mathrm{N}$ in the soil, an increase was observed until seven days of incubation, followed by a decrease (Figure 1).

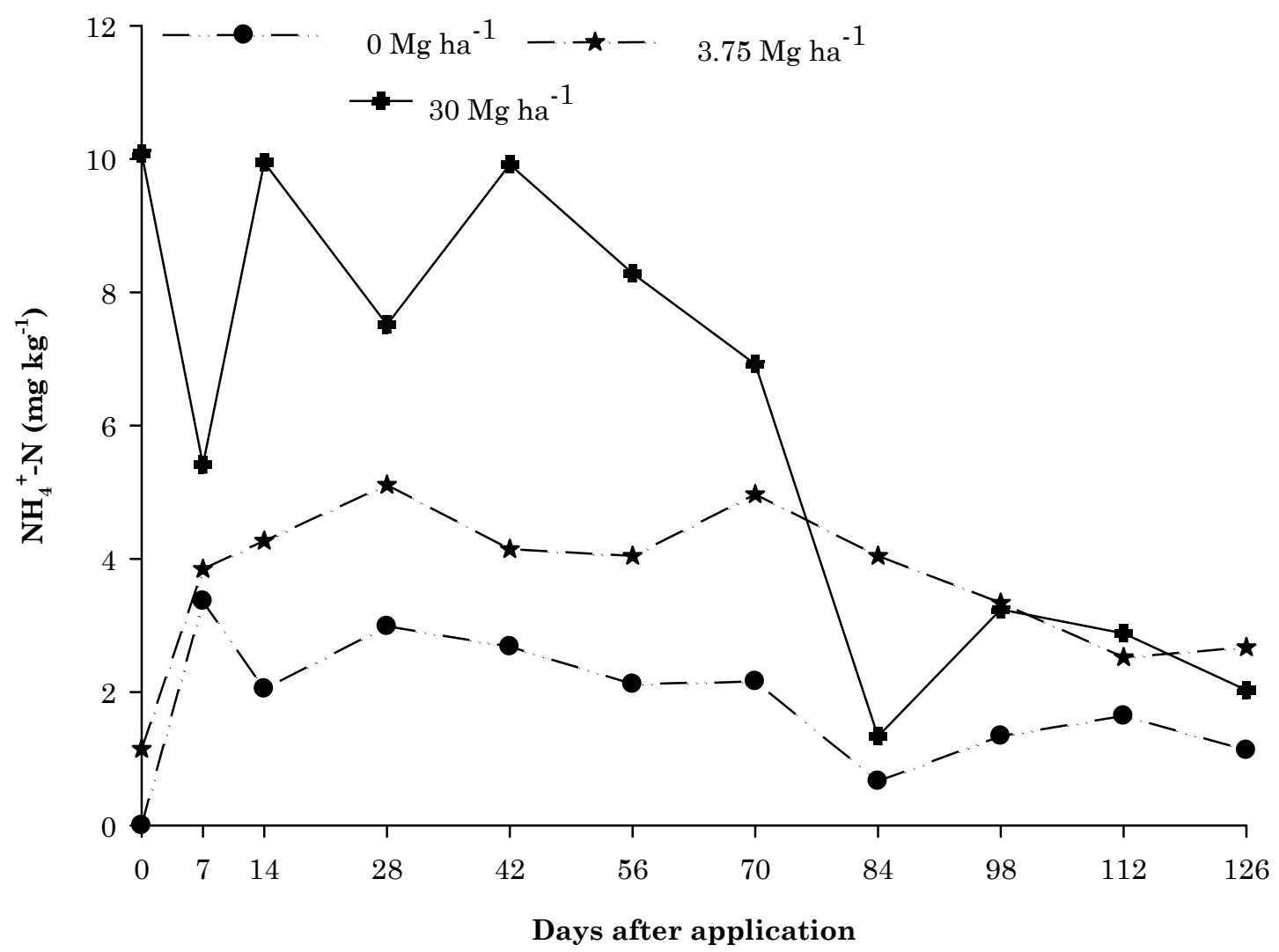

Figure 1. Evolution of ammonium content in NEOSSOLO FLÚVICO (Fluvents) as a function of doses of organic compost from residues of the production and slaughter of small ruminants, along 126 days of incubation.

For the values of $\mathrm{NO}_{3}{ }^{-} \mathrm{N}$ in the soil, there was a proportional increase to that of the applied doses of the compost (Figure 2). In order to better verify the behavior of ammonium and nitrate concentrations along the incubation, it was opted to present the data of the control and of the highest and lowest doses of the organic compost.

In general, the reductions of $\mathrm{NH}_{4}{ }^{+}-\mathrm{N}$ over time were accompanied by corresponding increments of $\mathrm{NO}_{3}{ }^{-}-\mathrm{N}$, evidencing the occurrence of nitrification since the beginning of incubation (MANTOVANI et al., 2006). In a study on $\mathrm{N}$ mineralization in poultry litter applied in Cambissolo Húmico (Inceptisol), the nitrate content increased simultaneously with the reduction in ammonium contents due to the oxidation of ammoniacal $\mathrm{N}$ by nitrifying bacteria (ROGERI et al., 2015); also according to the authors, the variation of ammonium and nitrate contents was characterized by a sigmoid curve, ascending for nitrate and descending for ammonium. 


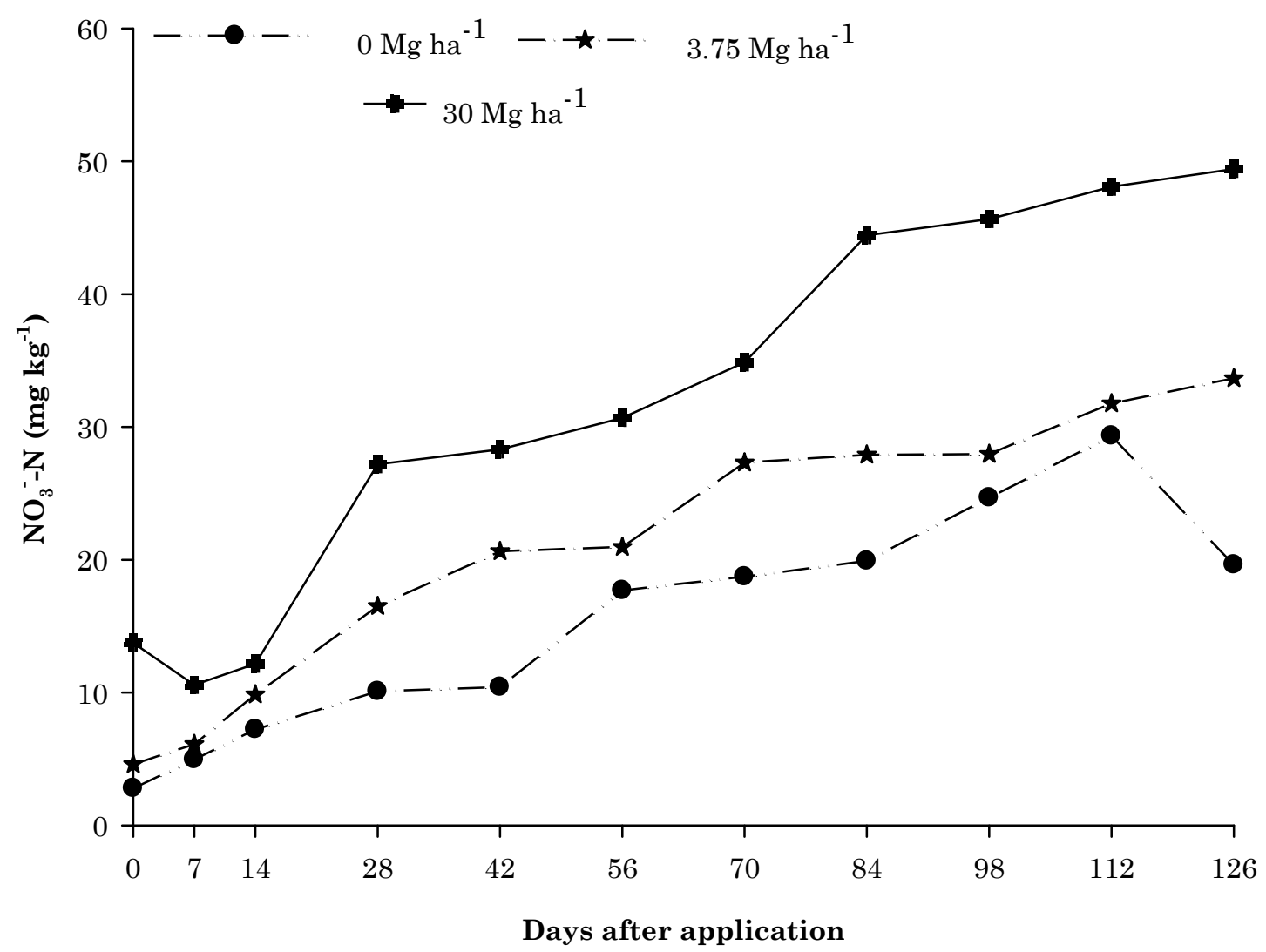

Figure 2. Evolution of nitrate content in NEOSSOLO FLÚVICO (Fluvents) as a function of doses of organic compost from residues of the production and slaughter of small ruminants, along 126 days of incubation.

The mineralization rate decreased with the increase in compost doses, ranging from 46.1 to $4.4 \%$ (Table 2). Although there are no standards for the fraction of mineralization for animal residues or similar composts, for composted sewage sludge the values are on the order of $10 \%$ (CONAMA, 2006). Furthermore, it is observed that there was no priming effect with the doses of organic compost applied.

Table 2. Potentially mineralizable nitrogen $\left(\mathrm{N}_{0}\right)$, nitrogen added as organic compost, mineralization constant $(\mathrm{k})$, half-life $\left(T^{1} / 2\right)$, coefficient of determination $\left(\mathrm{R}^{2}\right)$ and mineralization rate $(\mathrm{MR})$ of nitrogen of organic compost from residues of the production and slaughter of small ruminants, at 126 days after application in NEOSSOLO FLÚVICO (Fluvents).

\begin{tabular}{clccccc}
\hline Organic compost & $\mathrm{N}$ added & $\mathrm{N}_{0}$ & $\mathrm{k}$ & $\mathrm{T} 1 / 2$ & $\mathrm{R}^{2}$ & $\mathrm{MR}$ \\
\hline $\mathrm{Mg} \mathrm{ha}^{-1}$ & $--------\mathrm{mg} \mathrm{kg}^{-1}-------$ & day $^{-1}$ & days & & $\%$ \\
3.75 & 27.4 & 54.7 & 0.0071 & 97.6 & $0.82^{* *}$ & 46.1 \\
7.5 & 54.8 & 93.4 & 0.0212 & 32.7 & $0.72^{* *}$ & 38.9 \\
15 & 109.6 & 89.2 & 0.0276 & 25.1 & $0.77^{* *}$ & 15.2 \\
30 & 219.2 & 79.6 & 0.0334 & 20.8 & $0.81^{* *}$ & 4.4 \\
\hline
\end{tabular}

**Significant at $1 \%$ probability level.

Evaluating the mineralization of $\mathrm{N}$ from the application of poultry litter, Rogeri et al. (2015) observed low values recovered of $\mathrm{N}$ from organic fertilizer, which also has a low $\mathrm{C} / \mathrm{N}$ ratio (14). The authors believe that the low mineralization of $\mathrm{N}$ over time may be related to the stabilization of $\mathrm{N}$ compounds in forms of difficult mineralization, more humified (CARNEIRO et al., 2013). In addition, possible losses by volatilization and denitrification, which were not measured, cannot be ruled out.

The potentially mineralizable $\mathrm{N}$ calculated based on the accumulated mineralized inorganic $\mathrm{N}$ content $\left(\mathrm{NH}_{4}{ }^{+}-\mathrm{N}+\mathrm{NO}_{3}{ }^{-} \mathrm{N}\right)$ was higher at the dose of $7.5 \mathrm{Mg} \mathrm{ha}^{-1}\left(93.4 \mathrm{mg} \mathrm{kg}^{-1}\right)$ and lower for the dose of $3.75 \mathrm{Mg} \mathrm{ha}{ }^{-1}\left(54.7 \mathrm{mg} \mathrm{kg}{ }^{-1}\right.$ ) (Table 2), which represents an increase of $70 \%$ in comparison to the lowest dose.

Mineralization constants (k) also increased 
with the compost doses applied to the soil. Thus, $\mathrm{N}_{0}$ and $\mathrm{k}$ values are higher when there is a greater amount of substrate for soil microorganisms. Thus, $\mathrm{T}^{1} \frac{1}{2}$ decreased from the lowest to the highest doses of compost, which means that there was greater availability of $\mathrm{N}$ in a shorter time, at the highest doses, because there was an increase in the amount of $\mathrm{N}$ applied in the form of compost. Similar results for incubation test with whey without leaching were obtained by Kuhnen (2010), in Latossolo Vermelho distrófico (Oxisol) and Argissolo Vermelho-Amarelo distrófico (Ultisol), conducted in Jaboticabal, SP,
Brazil.

There was a reduction in $\mathrm{pH}$ over time (Figure 3) and a linear increase in electrical conductivity with the applied doses of compost, except in the absence of compost, in which the behavior was quadratic (Figure 4). Low $\mathrm{pH}$ values compromise nitrification, causing reduction when the values are below 5.5 (MANTOVANI et al., 2006). For electrical conductivity, in a study with urban garbage compost, the application of increasing amounts also led to increase in the electrical conductivity of the soil (MANTOVANI et al., 2006).



Figure 3. $\mathrm{pH}$ value in NEOSSOLO FLÚVICO (Fluvents) as a function of doses of organic compost from residues of the production and slaughter of small ruminants along 126 days of incubation. * Significant at 5\% probability level.

As discussed by Mantovani et al. (2006), the increase in electrical conductivity may not be the determining factor of the reduction in $\mathrm{N}$ mineralization fraction with the increase in the dose of organic compost. Furthermore, denitrification is negligible at soil moisture contents below $2 / 3$ of the water retention capacity, but it can occur in anaerobic microenvironments in well-drained soils, and denitrification can occur in soils that received large amounts of organic material with low $\mathrm{C} / \mathrm{N}$ ratio and with a large amount of easily decomposable $\mathrm{C}$.

According to an evaluation carried out by Boeira, Ligo and Dynia (2002), the increase in electrical conductivity may indirectly affect mineralization. Another justification for low mineralization is the accumulation of inorganic N, contributing to lower mineralization of this element, evidenced by the low $\mathrm{C} / \mathrm{N}$ ratio of the studied material (7.4:1). In a study on $\mathrm{N}$ mineralization in organic fertilizers, Sahrawat (1982) verified that the increase in nitrification is correlated with the increase in $\mathrm{pH}$ value, and in the present study there was a reduction (Figure 3), besides an increase in electrical conductivity (Figure 4). However, soils with $\mathrm{pH}$ greater than 6.0 showed that nitrate formation was not related to soil $\mathrm{pH}$, but values below 5.9 were observed according to the collections performed (Figure 3). The reduction in $\mathrm{pH}$ can be explained by the decomposition of organic matter, which would corroborate the decrease in mineralization (PATHAK; RAO, 1998; NEVE; HARTMAN; HOFMAN, 2003). There is variation in 
energy and nutrient demands in the efficiency of use of microbial $\mathrm{C}$, with consequent degradation of organic matter and release of $\mathrm{C}$ and $\mathrm{N}$, as a function of soil $\mathrm{pH}$, with optimum values in $\mathrm{pH}$ ranges for residue decomposition around 7.3 (AYE et al., 2017). In addition, the increase in electrical conductivity, due to the increase in organic materials, can reduce $\mathrm{N}$ mineralization, mainly nitrification (nitrate formation), that is, there is an inverse relationship between salinity and nitrate production (LAURA, 1974; PATHAK; RAO, 1998). The justification would be that the increase in the concentration of salts ( $\mathrm{Na}$ and $\mathrm{Ca}$ ) would affect the microbial population of the soil, delaying metabolic activities, because the nitrification process is performed by autotrophic bacteria, which require optimal conditions ( $\mathrm{pH}$, nutrients and low salinity) for their functioning (LAURA, 1974; PATHAK; RAO, 1998). Thus, it is justified that the dose of 7.5 $\mathrm{Mg} \mathrm{ha}{ }^{-1}$ promotes a higher value of potentially mineralizable $\mathrm{N}$, i.e., at the higher doses there may have been denitrification, as there was reduction in $\mathrm{pH}$ (Figure 3) and increase in electrical conductivity (Figure 4).

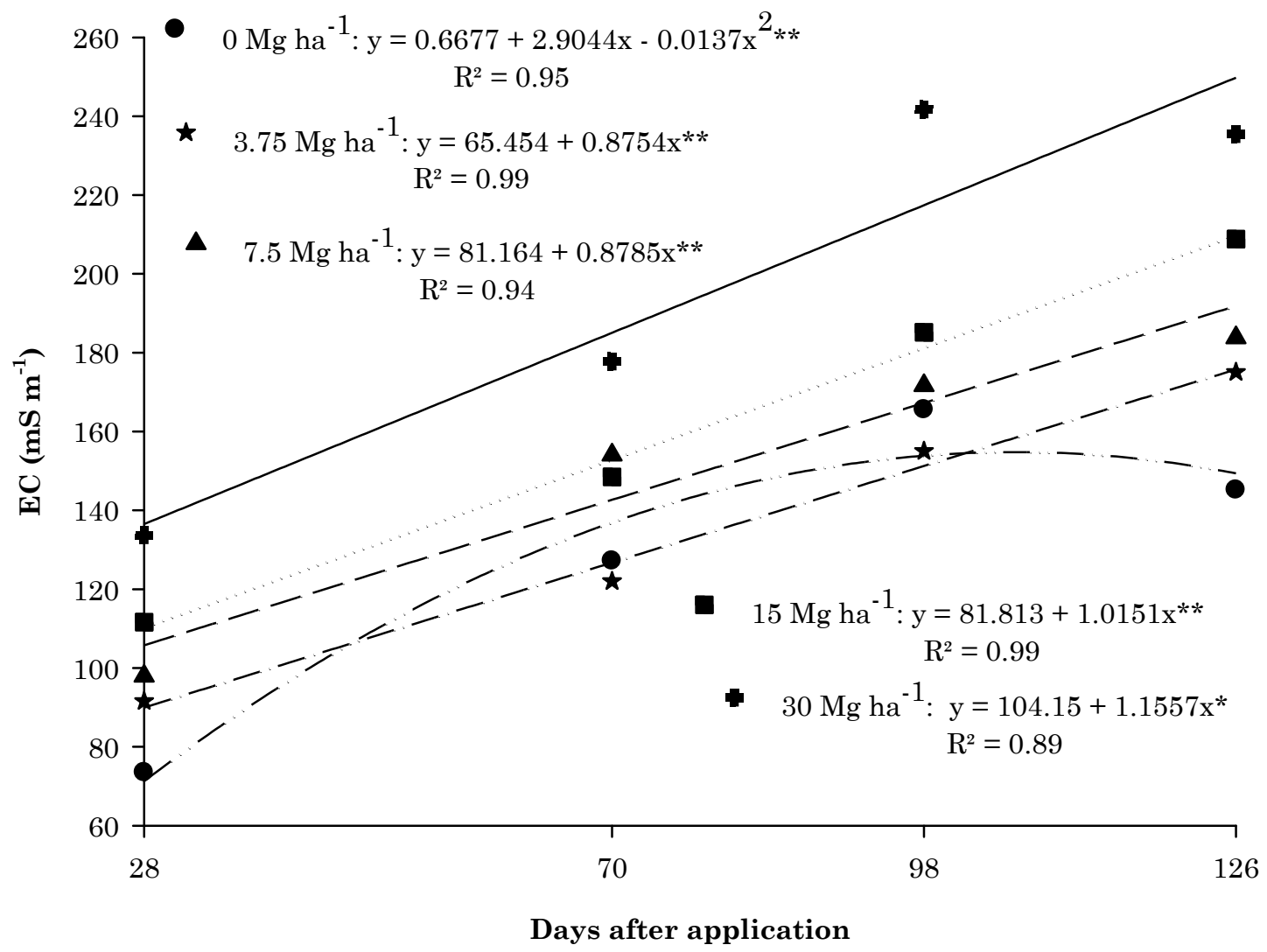

Figure 4. Electrical conductivity in NEOSSOLO FLÚVICO (Fluvents) as a function of doses of organic compost from residues of the production and slaughter of small ruminants along 126 days of incubation. ** Significant at $1 \%$ probability level.

In regard to $\mathrm{C}$ degradation, there is a reduction in the process, but the results may not follow the same logic of $\mathrm{N}$ mineralization, because the degradation is performed by heterotrophic microorganisms, which are less sensitive to the increase in salinity and with greater adaptability (LAURA, 1974; PATHAK; RAO, 1998).

The largest amount of $\mathrm{CO}_{2}-\mathrm{C}$ released occurred in the evaluation performed $24 \mathrm{~h}$ after the beginning of soil incubation (values above $300 \mathrm{mg}$ $\mathrm{kg}^{-1}$ day $^{-1}$ ), both in the absence and in the presence of the organic compost (Figure 5).
In subsequente valuations, there was a reduction in the amount of $\mathrm{CO}_{2}-\mathrm{C}$ released, with values close to $100 \mathrm{mg} \mathrm{kg}^{-1} \mathrm{day}^{-1}$ until the 9th day of incubation of the organic compost dose of $30 \mathrm{Mg} \mathrm{ha}^{-1}$ with the soil. The presence of more easily degradable compounds such as soluble carbohydrates and amino acids, which promotes rapid growth of soil microbial population (MARSTORP, 1996; BERNAL et al., 1998), combined with the re-wetting of soil samples, which breaks aggregates and exposes physically protected organic matter (FIERER; SCHIMEL, 2002), explain the rapid mineralization of $\mathrm{C}$ in the first days of incubation. 


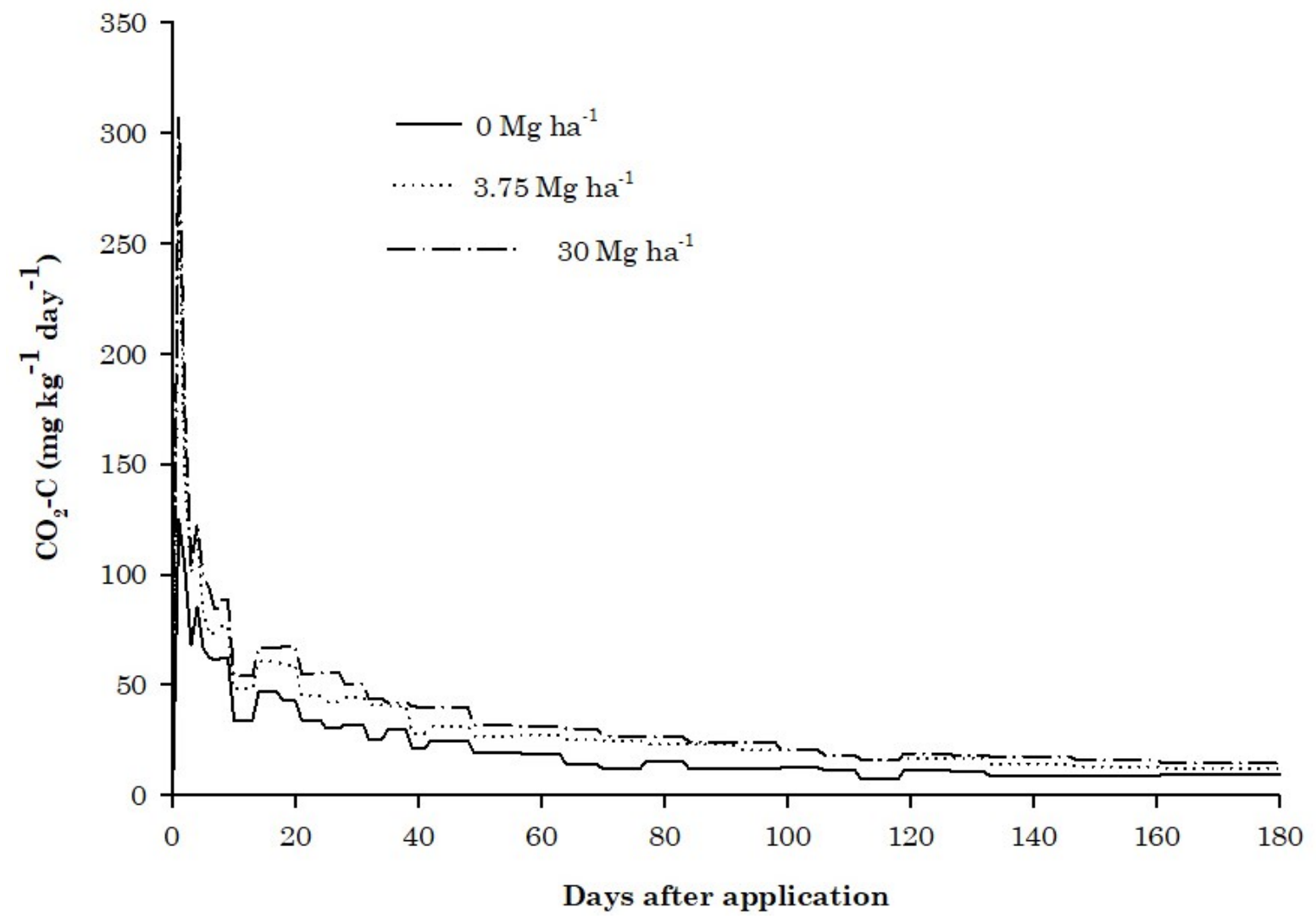

Figure 5. Evolution of $\mathrm{CO}_{2}-\mathrm{C}$ in NEOSSOLO FLÚVICO (Fluvents) as a function of doses of organic compost from residues of the production and slaughter of small ruminants, along 180 days of incubation.

Therefore, the greater amount of mineralized $\mathrm{C}$ in soils that received sewage sludge can be attributed to these compounds (PEDRA et al., 2007). In addition, favorable temperature and moisture conditions for microbial activity (FERNANDEZ et al., 2007) and the low $\mathrm{C} / \mathrm{N}$ ratio of the residue (7.4:1) favor $\mathrm{C}$ decomposition in the soil.

The accumulated amount of mineralized $\mathrm{C}$, at all doses of organic compost, was described by the exponential first-order kinetics model, with coefficients of determination ranging from 0.9721 to 0.9905 (Table 3). Other mathematical models have been used to describe the decomposition of organic residues, which differ in relation to the number of compartments, usually with a more labile organic fraction, which is rapidly mineralized, and at least another one of greater recalcitrance, which decomposes more slowly, as the simple exponential model, being another option for evaluation (PEREIRA et al., 2018).

Table 3. Potentially mineralizable carbon $\left(\mathrm{C}_{0}\right)$, carbon added in the form of organic compost, mineralization constant $(\mathrm{k})$, half-life $\left(T^{1 / 2}\right)$, coefficient of determination $\left(\mathrm{R}^{2}\right)$ and biodegradation rate $(\mathrm{BR})$ of carbon of organic compost from residues of the production and slaughter of small ruminants, at 180 days after application in NEOSSOLO FLÚVICO (Fluvents).

\begin{tabular}{ccccccc}
\hline Organic compost & $\mathrm{C}$ added & $\mathrm{C}_{0}$ & $\mathrm{k}$ & $\mathrm{T}^{1 / 2}$ & $\mathrm{R}^{2}$ & $\mathrm{BR}$ \\
\hline $\mathrm{Mg} \mathrm{ha}^{-1}$ & $--------\mathrm{mg} \mathrm{kg}^{-1}------$ & days $^{-1}$ & days & & $\%$ \\
3.75 & 203 & 490.1 & 0.0128 & 54.2 & $0.97^{* *}$ & 225.5 \\
7.5 & 406 & 396.5 & 0.0167 & 41.5 & $0.98^{* *}$ & 105.1 \\
15 & 813 & 435.8 & 0.0173 & 40.0 & $0.97 * *$ & 58.8 \\
30 & 1625 & 672.3 & 0.0146 & 47.5 & $0.99^{* *}$ & 40.7 \\
\hline
\end{tabular}

**Significant at $1 \%$ probability level. 
Potentially mineralizable $\mathrm{C}$ values ranged from 396.5 to $672.3 \mathrm{mg} \mathrm{kg}^{-1}$. The average time required for $50 \%$ of the $\mathrm{C}$ added in the form of organic compost to be mineralized was 40-54.2 days, which confirms the presence of easily decomposable $\mathrm{C}$ compounds in the residue.

The organic compost produced from carcasses, sheep waste and slaughterhouse waste had a k value equal to $0.01179 \mathrm{~g} \mathrm{day}^{-1}$ at $31{ }^{\circ} \mathrm{C}$ without water stress, in Luvissolo Crômico (Alfisol), and the application of this compost increased by $9.8 \%$ the decomposition rate of organic matter of the native soil (PEREIRA et al., 2018).

With the application of the organic compost doses of 3.75 and $7.5 \mathrm{Mg} \mathrm{ha}^{-1}$ (Table 3), more than $100 \%$ of the added $\mathrm{C}$ was mineralized until the 180 th day of incubation, indicating the occurrence of the priming effect. Thus, the addition of organic compost stimulated microorganisms to mineralize not only the $\mathrm{C}$ added in the form of residue, but also part of the $\mathrm{C}$ from soil organic matter (KUZYAKOV; FRIEDEL; STAHR, 2000). In a study with tannery sludge, applying the equivalent to $3 \mathrm{Mg} \mathrm{ha}^{-1}$ (dry basis) in sandy soil after 105 days of incubation, Martines, Andrade and Cardoso (2006) also verified priming effect. The reduction in degradation rate with the increase in the amount of residue can be explained, according to Wong et al. (1998), by the increase in the amount of organic C added, which exceeds the capacity of microorganisms to degrade the residue.

Considering the priming effect as a constant that modifies the rate of decomposition of organic matter of native soil is appropriate to explain the interactions of the soil with the applied organic material (PEREIRA et al., 2018).

At the organic compost doses of 15 and 30 $\mathrm{Mg} \mathrm{ha}{ }^{-1}$, the biodegradation rate was equal to 58.8 and $40.7 \%$, indicating accumulation of soil total organic C (TOC). At 180 days after the application of the organic compost, soil organic $\mathrm{C}$ content increased linearly, and at the highest dose applied there was an increase of $2 \mathrm{~g} \mathrm{~kg}^{-1}$ compared to the control treatment $\left(\mathrm{C}\right.$ content $_{(\mathrm{g} / \mathrm{kg})}=10.891+$ 0.061 doses $\left.\left(\mathrm{Mg} \mathrm{ha}^{-1}\right)^{* *}, \mathrm{R}^{2}=0.95\right)$. In experiments under controlled conditions, the increase in soil TOC with the application of organic residues is frequently reported (ANDRADE et al., 2015); however, in the field, this increase is only obtained with repeated applications or with materials of greater stability (SOUZA et al., 2014b).

The $\mathrm{C}$ biodegradation rate, higher than $40.7 \%$, was high when compared to other results. In a study with 47 residues of animal origin, Morvan, Nicolardot and Péan (2006) found that 5 to $62 \%$ of the added $\mathrm{C}$ was mineralized in 224 days of incubation with the soil. With the application of 40 $\mathrm{Mg} \mathrm{ha}{ }^{-1}$ of biosolids, Andrade, Oliveira and Cerri (2006) verified an average degradation rate of $21.63 \%$, after 70 days of incubation. According to these authors, the low value indicates the predominance of recalcitrant organic compounds, that is, those of difficult biological degradation in the soil. Rates ranging from 80.1 to $93.2 \%$ were found by Bernal et al. (1998) with the application of residues containing sewage and municipal waste as main constituents. These high rates can be explained by the fact that these composts were collected in the initial phase of the composting process and had a high proportion of easily degradable organic compounds.

The high correlation $\left(\mathrm{r}=0.88^{*}\right)$ between $\mathrm{CO}_{2}-\mathrm{C}$ accumulated at 180 days and the inorganic $\mathrm{N}$ accumulated at 126 days indicates that the $\mathrm{C}$ and $\mathrm{C}$ mineralization processes are interconnected. Thus, the nature of the substances present in the organic compost, as verified in the results obtained, is one of the determining factors in the intensity of $\mathrm{C}$ and $\mathrm{N}$ mineralization processes (FLAVEL; MURPHY, 2006). In a study with 47 residues of animal origin, Morvan, Nicolardot and Péan (2006) verified a positive correlation between mineralized $\mathrm{C}$ and the water-soluble fraction and the hemicellulose content of 47 residues of animal origin, which is justified by the fact that these materials with predominance of lignin and cellulose in their compositions have low rate of $\mathrm{C}$ mineralization. The degradation rate is also positively correlated with crude protein and negatively correlated with phenols and tannins (ANDRADE; OLIVEIRA; CERRI, 2006).

\section{CONCLUSIONS}

The organic compost from residues of the production and slaughter of goats and sheep increased the values of inorganic nitrogen and the concentration of organic carbon in Neossolo Flúvico (Fluvents), with increments of 70 and $69 \%$ at the doses of 7.5 and $30 \mathrm{Mg} \mathrm{ha}^{-1}$, respectively.

Organic carbon and nitrogen from the compost from residues of the production and slaughter of small ruminants are rapidly mineralized in the soil, with a half-life time of 45.8 days for carbon and 44.1 days for nitrogen, due to its low $\mathrm{C} / \mathrm{N}$ ratio $(7.4: 1)$.

\section{REFERENCES}

ABREU, M. F.; ANDRADE, J. C.; FALCÃO, A. A. Protocolos de análises químicas. In: ANDRADE, J. C.; ABREU, M. F. (Eds). Análise química de resíduos sólidos para monitoramento e estudos agroambientais. Campinas, SP: Instituto Agronômico, 2006. cap. 10, p. 121-158.

ANDERSON, J. P. E. Soil respiration. In: PAGE, A. L.; MILlER, R. H.; KEENEY, D. R. (Eds). 
Methods of soil analysis: chemical and microbiological properties. Madison, WI: American Society of Agronomy, Soil Science Society of America, 1982. p. 831- 845.

ANDRADE, C. A.; OLIVEIRA, C.; CERRI, C. C. Cinética de degradação da matéria orgânica de biossólidos após aplicação no solo e relação com a composição química inicial. Bragantia, 65: 659668, 2006.

ANDRADE, C. A. et al. Mineralização e efeitos de biocarvão de cama de frango sobre a capacidade de troca catiônica do solo. Pesquisa Agropecuária Brasileira, 50: 407-416, 2015.

ALVES, V. M. C. et al. Milho. In: RIBEIRO, A. C.; GUIMARÃES, P. T. G.; ALVAREZ, V. H. V. (Eds). Recomendações de Fertilidade do Solo do Estado de Minas Gerais - $5^{\mathbf{a}}$ Aproximação. Viçosa, MG: Comissão de Fertilidade do Solo do Estado de Minas Gerais, 1999. p. 314-316.

AYE, N. S. et al. Residue addition and liming history interactively enhance mineralization of native organic carbon in acid soils. Biology and Fertility of Soils, 53: 61-75, 2017.

BERNAL, M. P. et al. Carbon mineralization from organic wastes at different composting stages during their incubation with soil. Agriculture, Ecosystem \& Environment, 69: 175-189, 1998.

BOEIRA, R. C.; LIGO, M. A. V.; DYNIA, J. F. Mineralização de nitrogênio em solo tropical tratado com lodos de esgoto. Pesquisa Agropecuária Brasileira, 37: 1639-1647, 2002.

BOEIRA, R. C.; MAXIMILIANO, V. C. B. Determinação da fração de mineralização de nitrogênio de lodos de esgoto: um método alternativo. Jaguariúna, SP: Embrapa MeioAmbiente, 2004. 3 p.

BRASIL. Ministério da Agricultura, Pecuária e Abastecimento. Serviço de Defesa Animal. Instrução Normativa no 8 de 25 de março de 2004. Proibe em todo o território nacional a produção, a comercialização e a utilização de produtos destinados à alimentação de ruminantes que contenham em sua composição proteínas e gorduras de origem animal. Diário Oficial da União, Brasília, DF, 26 de março de 2004. Seção 1. p. 5.

CANTARELlA, H.; TRIVELIN, P. C. O. Determinação de nitrogênio inorgânico em solo pelo método da destilação a vapor. In: RAIJ, B. VAN. (Ed.). Análise química para avaliação da fertilidade de solos tropicais. Campinas, SP:
Instituto Agronômico, 2001, p. 270-276.

CARNEIRO, W. J. O. et al. Mineralização de nitrogênio em Latossolos adubados com resíduos orgânicos. Revista Brasileira de Ciência do Solo, 37: 715-725, 2013

CONSELHO NACIONAL DO MEIO AMBIENTE CONAMA. Ministério do Meio Ambiente. Resolução CONAMA n ${ }^{\circ} \mathbf{3 7 5}$ de 29 de agosto de 2006. Define critérios e procedimentos, para o uso agrícola de lodos de esgoto gerados em estações de tratamento de esgoto sanitário e seus produtos derivados, e dá outras providências. Brasília, 2006. Disponível em: <http://www2.mma.gov.br/port/ conama/res/res06/res37506.pdf $>$. Acesso em: 26 de abr. 2020 .

COSCIONE, A. R.; ANDRADE, C. A. Protocolos para a avaliação dinâmica de resíduos orgânicos no solo. In: ANDRADE, J. C.; ABREU, M. F. (Eds). Análise química de resíduos sólidos para monitoramento e estudos agroambientais. Campinas, SP: Instituto Agronômico, 2006. p. 15977.

FERNANDEZ, J. M. et al. Carbon mineralization in an arid soil amended with thermally-dried and composted sewage sludge. Geoderma, 137: $497-$ 503, 2007.

FIERER, N.; SCHIMEL J. P. Effects of dryingrewetting frequency on soil carbon and nitrogen transformations. Soil Biology \& Biochemistry, 34: 777-87, 2002.

FLAVEL, T. C.; MURPHY, D. V. Carbon and nitrogen mineralization rates after application of organic amendments to soil. Journal of Environmental Quality, 35: 183-193, 2006.

KUHNEN, F. Mineralização do nitrogênio do soro ácido de leite. 2010. 45 f. Dissertação (Mestrado em Agronomia: Área de Concentração em Ciência do Solo) - Faculdade de Ciências Agrárias e Veterinárias - Universidade Estadual Paulista "Júlio de Mesquita Filho", Jaboticabal, 2010.

KUZYAKOV, Y.; FRIEDEL, J. K.; STAHR, K. Review of mechanisms and quantification of priming effects. Soil Biology \& Biochemistry, 32: 14851498,2000

LAURA, R. D. Effects of alkali salts on carbon and nitrogen mineralization of organic matter in soil. Plant and Soil, 44: 587-596, 1974.

MAgAlhãeS, K. A. et al. Panorama da ovinocultura e da caprinocultura a partir do Censo Agropecuário 2017. Sobral, CE: Embrapa 
Caprinos e Ovinos, 2018. 18 p.

MANTOVANI, J. R. et al. Mineralização de carbono e de nitrogênio provenientes de composto de lixo urbano em Argissolo. Revista Brasileira de Ciência Solo, 30: 677-684, 2006.

MARSTORP, H. Influence of soluble carbohydrates, free amino acids, and protein content on the decomposition of Lolium multiflorum shoots. Biology and Fertility of Soils, 21: 257-263, 1996.

MARTINES, A. M.; ANDRADE, C. A.; CARDOSO, E. J. B. N. Mineralização do carbono orgânico em solos tratados com lodo de curtume. Pesquisa Agropecuária Brasileira, 41: 1149-1155, 2006.

MENEZES, R. S. C. et al. Biogeochemical cycling in terrestrial ecosystems of the Caatinga Biome. Brazilian Journal of Biology, 72: 643-653, 2012.

MORVAN, T.; NICOLARDOT, B.; PÉAN, L. Biochemical composition and kinetics of $\mathrm{C}$ and $\mathrm{N}$ mineralization of animal wastes: a typological approach. Biology and Fertility of Soils, 42: 513$522,2006$.

NEVE, S.; HARTMAN, R.; HOFMAN, G. Temperature effects on $\mathrm{N}$ mineralizations: changes in soil solution composition and determination of temperature coefficients by TDR. European Journal of Soil Science, 54: 49-61, 2003.

OLIVEIRA, E. L. et al. Compostagem de resíduos da produção e abate de pequenos ruminantes. 1 . ed. Sobral, CE: Embrapa Caprinos e Ovinos, 2015. $11 \mathrm{p}$.

PATHAK, H.; RAO, D. L. N. Carbon and nitrogen mineralization from added organic matter in saline and alkali soils. Soil Biology \& Biochemistry, 6: 695-702, 1998.

PAULA, J. R. et al. Mineralização do carbono e nitrogênio de resíduos aplicados ao solo em campo. Revista Brasileira de Ciência do Solo, 37: 17291741, 2013.

PEDRA, F. et al. Effects of municipal solid waste and sewage sludge on mineralization of soil organic matter. Soil Biology \& Biochemistry, 39: 13751382, 2007.

PEREIRA, M. S. et al. Organic carbon decomposition in soil amended with organic compost from slaughterhouse residues. Journal of Agricultural Science, 10: 7-14, 2018.
ROGERI, D. A. et al. Mineralização e nitrificação do nitrogênio proveniente da cama de aves aplicada ao solo. Revista Brasileira de Engenharia Agrícola e Ambiental, 19: 534-540, 2015.

SAHRAWAT, K. L. Nitrification in some tropical soils. Plant and Soil, 65: 281-286, 1982.

SOUZA, H. A. et al. Níveis críticos para atributos do solo pela distribuição normal reduzida em culturas anuais de subsistencia. Revista Brasileira de Engenharia Agrícola e Ambiental, 18: 425-430, 2014a.

SOUZA, H. A. et al. Uso fertilizante do subproduto da agroindústria processadora de goiabas I: atributos químicos do solo. Revista Brasileira de Fruticultura, 36: 713-724, 2014b.

SOUZA, H. A. et al. Características físicas e microbiológicas de compostagem de resíduos animais. Arquivo Brasileiro de Medicina Veterinária e Zootecnia, 71: 291-302, 2019.

STANFORD, G.; SMITH, S. J. Nitrogen mineralization potentials of soil. Soil Science Society of America Journal, 3: 465-471, 1972.

WONG, J. W. C. et al. Effect of sewage sludge amendment on soil microbial activity and nutrient mineralization. Environment International, 24: 935-943, 1998 